\title{
Fraud, Corruption and COVID-19: Rules and Regulations Fallacy Exposed
}

\author{
Lovemore Thusabantu, Lecturer, Accounting and Finance Department \\ BA ISAGO University \\ 11 Koi Street, Peolwane, Gaborone, Botswana, Private Bag BR94, Gaborone
}

\begin{abstract}
The pandemic has brought about the experience never seen before and challenges of human suffering, coupled with a lot of economic uncertainty on the global stage. The crisis can easily create corruption and fraudulent activities. Consequently, it is of paramount importance that both the government and private sectors work together to avert the huge devastation by the pandemic. As such, other risks will emerge in the short to long-term as the consequences and impact of this pandemic unfold. Addressing and identifying corruption are therefore high in the scale of importance and crucial to the survival of the people. Gaining public confidence is very important as all countries around the world seize themselves in the fight against COVID-19. This study is therefore intended to guide those who are responsible for the crafting of laws, policy makers, law enforcement authorities, and the private sector and donator agencies, and those who make appointment of public officers to ensure that the worldwide response to the COVID-19 pandemic is not undermined by corruption and bribery as its major objective. The survey design was used in the study. Articles were collected from targeted Southern Africa Development Community (SADC) member states and compare with some European and Latin American countries. The articles were surveyed for information regarding policies, rules regulations and the type of people who handled the acquisition of Personal Protective Equipment (PPE).It was observed that while rules and regulations might have been in place, the lack of appropriate personnel to carry out the function was a major blow. Those who were appointed were either politically connected or lack the necessary characteristics to perform such noble duties. Many concentrated on lining up their pockets and those of their friends. People lacked integrity, compassionate and the understanding of the impact of the COVIC-19 to the generality of the people.Regulations alone are not enough, since people can choose to ignore them. It is the integrity, which in most cases was lacking, people who are balanced and complete and have competency, humility and coverage to say NO to corruption fraudulent activities. Governments take for granted the attitudes of the citizens concerning the behaviour of some government officials. When these issues are raised, those in positions of authority take such issues as minor. This is evidenced by what TI experienced in Brasil where they did not get joy in trying to get information regarding reported corruption.It was also recommended that it might be necessary to publicise the names of those who are appointed to public offices so that the public can comment on them before they are appointed. Ministers who are appointed are not appointed to perform only the mandate of their political parties but that of the nations at large.It is further recommended that those in the public office should be selected on the basis of honesty and integrity and not political affiliation or connections. They should be people who are willing to serve the public irrespective of the benefits accruing to the offices they will be occupying. They should also have a thorough understanding of social forces that can perpetuate the corrupt practices.
\end{abstract}

Keywords: COVID-19, corruption and fraud, Huwan, rules and regulations

DOI: $10.7176 /$ RJFA/12-12-03

Publication date:June $30^{\text {th }} 2021$

\section{Introduction}

The global economic crunch had a big impact on the private sector all over the world and so is the Coronavirus which can be characterised as next to bombing to destroy the whole world. The coming into being of this virus which believed to have originated in a market in the province of Huwan in China that engaged in the corruption and illegal trade of exotic wildlife whereby the zoonotic disease was transferred to humans put nations to panic as the first person to have died of the virus was confirmed on 11 January 2020, Steingruber, S (2020) et.al. This was followed by a publication on 20 January 2020, by a Chinese epidemiologists with the Centre for Disease Control and Prevention stating that the first cluster of patients with pneumonia of an unknown cause had been identified on $21^{\text {st }}$ December 2019, Evie (2020). In no time, the virus had spread all over the world and the World Health Organisation (WHO) declares a global health emergency as thousands of new cases were reported in China. Evie (2020) further observes that by $23^{\text {rd }}$ March 2020 worldwide figures stood at more than 270000 cases and 11000 deaths. This put world leaders to panic resulting in G20 leaders to meet virtually to discuss the coronavirus crisis.

To alert and ensure that the world take the virus seriously as it was capable of wipping out nations both economically and socially, WHO declared the virus a pandemic on $30^{\text {th }}$ January 2020 amid thousands of new cases in China. This was at the back drop of the death of the Chinese Doctor, Dr. Li Wenliang, after contracting the virus, who tried to ring early alarms that a cluster of infections could spin out of control, Evie (2020). It also came 
up with protocols to be followed to limit the spread of the virus as it had started to kill the front line people. One such protocol was the wearing of Personal Protective Equipment (PPE) resulting in a rush to acquire such equipment as directed by WHO. Rules and regulations were either ignored where they existed or short cuts made. In the course of trying to acquire the PPEs as quickly as possible, some amongst those who were tasked with the responsibility of acquiring such PPEs took the opportunity to enrich them.

In many countries, responses to COVID-19 have seen breaches of anti-corruption standards such as avoiding tenders in procurement processes, or persons in power taking advantage of the crisis to increase their personal benefits.

In Norway some doctors are reported to be breaking the guidelines from the state medicine agency that has issued rationing of medicines that may help against COVID-19 by continuing to write prescriptions for their family and friends while in Germany, six million ordered to protect health workers from the coronavirus went missing at an airport in Kenya, (Steingruber, S, et. al) (2020).

Throughout March 2020 and beyond, there has been a wave of corruption-related incidents, decreasing transparency and accountability, as well as to some extent, manipulative political propaganda from all over the world. In the United States of America (USA), concerns were high that those in positions of power will bend what is left of the regulatory, policy and legal institutions for their private benefit, or influence decisions for bailouts and stimulus packages for industries groups and at the expense of public interest. It is even believed that COVID19 itself might have emerged as a result of corruption (Steingruber, S, et. al) (2020).

Paul, Fontenot, Partner, Oceania Fraud Investigation and Dispute Services (2019) define fraud as an "international act, involving the use of deception to obtain an unjust or illegal advantage." They further post that fraud and corruption which are strongly related remain high in both the private sector and public sector despite sterling efforts being made by governments world-wide to reduce it. Instead, it seems to be increasing despite the various rules and regulations put into place. It can typically be viewed as theft of cash, misappropriation of assets or falsification of accounts in order to achieve an unjust or illegal advantage or cause some disadvantages. Corruption on the other hand can be defined as dishonest activity in which an employee or an entity acts contrary to the interests of the entity, in order to achieve some personal gain. It is a subset of fraud and involves the offer or makings of some benefits to another part to provide an advantage to an individual or entity.

Procurement fraud is any fraud relating to the purchasing of goods and services. This fraud covers the entire procure-to-pay lifecycle; including fraud in the tender/bidder selection and contract award stages; as well as fraud occurring during the life of the contract. It also involves kickbacks, Conflict Of Interest Company and deliberate mismanagement of company business. Corruption, the abuse of public office for private gain, is about more than wasted money. It erodes the social contract and corrodes the government's ability to help grow the economy in a way that benefits all citizens. It is known that corruption was a challenge before the COVID-19 crisis, but the becoming into of it, has heightened the importance of stronger governance for these reasons. So what could the problem which causes fraud and corruption not being eradicated despite all the efforts being put in place?

\section{Problem Statement}

To find out if there is any other way apart from coming up with rules and regulations that can be used to eradicate fraud and corruption. This comes at the backdrop of increased fraud and corruption rates despite many elaborate rules and regulations being put in place across the globe.

\section{Literature Review}

Bishop, T and Hydoski, F(2020), explained how in addition to reducing profits, fraud and corruption can lead to cohort of other negative consequences which include, reputational losses, accesses to capital brand power, market position and competitive advantage.

Ronald, J, Burke and Copper, C.L (2009) presented causes, consequences and choices to corruption situations. They further post that individuals are likely to participate in corrupt behaviour or turn to a blind eye towards it in order to fit into or belong to the organisation and if they strongly identify with the organisation. In many instances, we have observed people getting into trouble simply because they want to associate with people who have power or money which they do not know how it was obtained.

Bryan, K et al (2010) developed a model of fraud in which they say, "like any other market, the carding underground consists of some resource input that is extracted and processed by suppliers, brought to market and retailed by middleman, and finally purchased and consumed by the demand pool." This assertion can be equalled to what happed in Zimbabwe where the Minister of Health and Child Care is alleged to acted corruptly through a middle man in the procurement of PPE worth USD60million leading to loss of his job.

In their paper, Fraud, Corruption in the Private Sector and Internal Control Quality, Luminito (2011), concluded that because of fraud and corruption, governments world-wide are becoming more interested in securing information and financial data so as to combat fraud. But still, the war has not been won and looks like it is far from being won. 
IMFBlocg (2020), a forum for the current views of the International Monetary Fund (IMF) staff and officials on pressing economic and policy issues notes that because governments are playing a bigger role in the economy increases opportunities for corruption. The block further notes that governments around the world are playing a bigger role in the economy to combat the pandemic and provide economic life lives to people and firms. The expanded role is therefore crucial but it also increases opportunities for corruption. To help ensure that the money and measures are helping the people who need it most, governments need timely and transparent reporting, expost audits and accountability procedures, and use cooperation with civil society and the private sector.

It further notes that although corruption was a problem before the crisis, the COVID-19 pandemic has heightened the importance of stronger governance, chiefly because, in trying to combat fraud and corruption, IMF ensured that borrowing countries have committed to (i) undertake and publish independent ex-post audits of crisis related spending and (ii) publish crisis-related procurement contracts on the governments' websites including identifying the companies awarded the contract and their beneficial owners. To complement IMF, media has played a critical role in exposing corruption. However, in some instances, this has caused journalists to have running battles with governments. A classic example is that of Hopewell Chin'ono, a journalist in Zimbabwe who has been in and out of jail simply because he reported on deals seemingly shrouded in fraud and corruption, Magaisa (2020).

Pitso (2020) observes that Botswana was reeling from a new strain of corruption which was riding on the constraints' of the COVID-19 pandemic. While procurement of goods and services during an emergency requires speed and decisive action, this however can open the "back door" for corruption. The paper further observes that in about 48 days, the Directorate on Corruption, Economic Crime (DCEC) had received hundreds of reports about corruption linked to the COVID-19 pandemic and already government had fired two high profile officers, suspended at least ten senior officers and disbanded one procurement department due to misconduct and corruption linked to COVID-19 pandemic. Transparency International (TI) which had joined hands with Botswana Centre for Public Integrity warned that as the coronavirus pandemic continues running havoc in Southern Africa so do concerns about the corruption and the misuse of public funds and most to be hard hit with corruption were local authorities. The President of Botswana Association of Local Authorities (BALA), is quoted as saying: "we have dispatched our team of officers but kindly note that we cannot respond to specific investigations and names of people under investigation since this is contrary to the DCEC policy", when asked by the Sunday Standard reporter, Pitse (2020).

According to the Maverick newspaper of South Africa (2020), the President recently signed a proclamation authorising the Special Investigating Unit (SIU) to probe, in any State institution, allegations of corruption during or related to the COVID-19 National State of Disaster. To try and fight the corruption in the COVID-19 pandemic, the government of South Africa put together a collaborative coordinating centre that strengthens the effort among law enforcement agencies so to prevent, detect, investigate and prosecute COVID-19 related corruption cases, bringing together nine State Institutions, all to assist in the fight against corruption. At least 36 cases are currently reported to be at various stages of investigation and prosecution for how part of about R500billion covering social and economic plagued by corruption has been used.

Steingruber, S et al. (2020), the European continent was the epicentre of the outbreak with Italy, one of the countries hit hard by COVID-19. An agricultural company won a contract to supply the government with face masks was already under investigation and the bid had been blocked. A hand book which focused on the use of legal instruments already available was crafted. The hand book focused on the application of those existing regulatory framework and required the speedy facilitation of awarding methods, the direct award, the negotiated procedures without publication of the call for tenders as well as the reduction of deadlines for the submission of tenders, the early execution of the contract and the early performance of the contract as a matter of urgency to reduce corruption. Little did they know that they were opening a window of opportunists? Those who were interested in their own personal interests and pockets.

Steigruber, S et al. (2020) further notes that Vucic, the Serbian President publicly indicated that due to a lack of ventilators available on the European market; he was "forced" to acquire them on the semi-grey market raising suspicion for the integrity of the procurement procedure. He is quoted as saying "you can prosecute me one day for providing respiratory to the people." This could be taken to mean that he knowingly did something wrong behind the proposition of helping the public.

In Zimbabwe, a Minister lost his job because of dubious deals involving the procurement of PPEs. In his Big Saturday Ready (BSR), Magaisa (2020), in reference to the Farm Mechanisation Scheme facilitated by Reserve Bank of Zimbabwe (RBZ), argues that corruption imposes a high cost on society. He posits that the bill for the Farm Mechanisation Scheme is an additional tax on society since it is the tax-paper who bears the cost. He further describes it as an unconscionable tax. Sasha (2020) reports the Commissioner of Taxes, Bonakele, B, in South Africa who explains that the role of the Commission was discourage firms from engaging in price gouging of essential goods during the period of pandemic. This best known for manufacturing the Burnshield range of medical products, had inflated the selling price on a box of 20 respiratory masks from P139.00 excluding Value Added 
Tax (VAT) on 14thFebruary 2020 to P670 by $23^{\text {rd }}$ March 2020 , a $382 \%$ price increase, in five weeks. Mahlaka (2020) also noted that the Treasury has strengthened its oversight hand on COVID-19 emergency procurement by National government's departments, provinces and authorities. The Auditor General's office would now be required to audit the expenditure of government arms on a daily or weekly basis, rather than examine their financial books every six or twelve months. This explains the scale at which corruption has escalated in the country.

To further buttress the extent to which corruption has spread world-wide, prosecutors in Sarajevo were probing whether there was a way any criminal activity regarding the choice to award a multi-million deal concerning the importation of 100 respirators from China to a fruit and vegetable processing company. Local media on $29^{\text {th }}$ April 2020, that "FH Srebrenica Malina" won a tender worth 10.5million Bosnian Marks to import the respirators from Beijing, China. To defend the company's wrong doing, the owner of the company, Hodzic, however, posits that everyone knows that ventilators were currently the most sought after goods in the world, and the biggest and most wealthy countries are having problems in procuring them. He further said that this makes the company even more satisfied that - it - managed to use its business relations with its partners in China and it strengthened its health care system with the procurement. The company did not find anything wrong with the way they had procured the PPE from China. Be that it may, Milisevic (2020), the Finance Minister of Bosnia's Federation $(\mathrm{FBIH})$ region and Commander of the FBIH Crisis Headquarters, argued that the tenders seems suspicious, and therefore needed to be investigated. All this indicates the extent to which corruption has deeply rooted itself in many countries in the world

Corruption is so rampant in the world to the extent that as of May 2020, Ecuador, the country with the highest number of COVID-19 deaths per capita in the Latin America region had received numerous complaints of overpricing around the procurement of medical supplies and medicine, having led to the resignation of the Minister of Health. This led to the National Anti-Corruption Commission pushing for the state to cut out the middlemen from these purchases and has called for a strict vigilance of the public purchasing to ensure that the public health system can cope with the oncoming infected people.

In Paraguay, accusations of overpricing and suspicious of kickbacks in the purchase of face-masks led to the dismissals and resignations at both the National Directorate of Civil Aviation (DINAC) and PETROPAR, the national oil company although in neighbouring Uruguay, overpricing has not been a big problem, posts Leites (2020).

According to Transparency International (TI) (2020), Basil has experienced a back-and-forth of government policies that restrict answers to information requests which it has spoken against together with other Brazilian organisations since the crisis started. This lack of transparency has made it possible for ruminants in countries to perpetuate corruption without hindrance.

In a research conducted by Pricewaterhouse Coopers (PWC) on 8 European member states and 5 sector industries, about 20\% of Gross Domestic Product (GDP) in European Union (EU)'s public procurement is lost in corruption.

Ernst and Young (2010) noted that the mining and metals sector is one of the most regulated around the world where regulation licenses and approvals need to be sought from government officials for the exploration, development, construction and operation of a mine. The process results in officials who have the power to block, delay or frustrates a project may attempt to solicit bribes for the benign exercise of that power. The report further noted that cultural divide as a constant problem for mining operating in different countries as it often provide countries who find it difficult to apply the same business processes, policies and procedures across countries with differing cultures. It further notes that bribes can be demanded and paid to favour a request for mining concessions, get a permit or approval, speed up bureaucratic processes or secure favourable contract conditions.

\section{Methodology}

Survey design was used in the study. Articles were collected from targeted European countries, Latin America, America and Southern Africa Development Community (SADC) members and analysed. Information from three SADC members, Botswana, South Africa and Zimbabwe was gathered through the reading of published articles and newspapers on those countries regarding the procurement of COVID-19 and what governments' initiatives were sounding the pandemic. In particular articles were surveyed for information regarding the policies and rules and regulation in place to guard against corruption and fraudulent activities could arise during the procurement of PPE.

The effectiveness of these policies and regulations were surveyed. In particular the rapidness in which a case is handled once reported and whether those involved charged with corruption and fraud were convicted.

The weaknesses of the policies were also considered. A design involves collecting data for all the members of the population. The method was used by Muchiri (2006) who carried out a survey of companies listed on the Nairobi Stock Exchange (NSE) on determination of dividend-pay-out ratio.

The population varied from country to country depending on the availability of reported issues on COVID19 corruption on the procurement and awarding of PPE tenders. 
The survey covered the period from March to August 2020.

In South Africa, the President recently signed a proclamation authorising the Special Investigation Unit (SIP) to probe, in any state institution, allegations of corruption during or related to the COVID-19 national state of disaster. Furthermore, a collaborative coordinating centre was put together to strengthen the efforts among law enforcement agencies to prosecute COVID-19 related corruption cases, but by the end of the selected period, no known cases have prosecuted and convicted.

In Zimbabwe, through the Zimbabwe Anti-Corruption Commission, no known cases of COVID-19 corruption cases have been prosecuted and convicted. While policies and regulations are in place, it appears that they are not strong or tight enough to ensure conviction of those involved in the seemingly fraudulent and corruption activities.

\section{Findings and Discussions}

From the discussions engaged above, it is evident that:

i. Governments take for granted the attitudes of the citizens concerning the behaviour of some government officials. When these issues are raised, those in positions of authority take such issues as minor. This is evidenced by what TI experienced in Brasil where they did not get joy in trying to get information regarding reported corruption.

ii. Suspicion regarding corruption is not reported in many countries possibly because of culture divide. However, this was not the case in Bosnia where the Finance Minister of Bosnia's Federation (FBIH) region and Commander of the FBIH Crisis Headquarters, argued that the gender which seemed suspicious should be investigated so that the government can gain the trust of the public.

iii. No short cuts should be tolerated in the procurement of PPE or any government procurement for that matter. While adequate policies may have been in place, where procurement officers are given latitude to do as they wish because of the emergency, they are likely to do the unexpected. They will either favour their friends in the awarding of the tenders or simply award their families. This is evidenced by the Norwegian doctors who went against the government policy in the prescription of COVID-19 diseases. It was also observed in South Africa and Zimbabwe where the current Secretary General of the party's relatives was awarded handsomely while in Zimbabwe the Minister of Health, although dismissed, is alleged to be a close relative of the Highest Office and no evidence of tendering was proffered in the acquisition of PPE in which he was alleged to have improperly gained over US\$60million.

iv. Due to the emergency of the pandemic, many procedures were ignored so that the purchases could be easily carried out without any impediment. This opened windows for scrupulous government employees and those connected to source of decision making.

\section{Recommendations}

From the foregoing, it has become evident that many countries are facing challenges in the procurement of COVID-19 PPE in order to fight the pandemic resulting in the G20 countries convening a meeting on how to fight the pandemic. It is further observed that while other people are genuinely fighting the pandemic, there are those amongst the generality of people both in public and private sectors who are bent on profiteering out of the situation. The Zimbabwean and Bosnian situations are classic examples of such people. There are also those who lack integrity and compassion towards the people they lead. There are also people who work but not getting enough to support their family irrespective of the fact that they will be working on the front line, where they risky their own lives and those of their families. In view of the above and the literature analysed above, it is recommended that:

1. Those in the public office should be selected on the basis of honesty and integrity and not political affiliation or connections. They should be people who are willing to serve the public irrespective of the benefits accruing to the offices they will be occupying. They should also have a thorough understanding of social forces that can perpetuate the corrupt practices.

2. Rules and regulations should be regularly reviewed and tightened so much so that no loopholes are left along the procurement value chain. There should be checks and balances at each level of decision making to ensure that the right decision is made. To assist in this decision, technological innovations should be used to ensure that corruption is limited.

3. The involvement of civil society entities, such as TI, in their monitoring roles, cannot be overemphasised. They should be given more powers in information request so that they keep the pressure on would-be fraudulent people on the run. A classic case is in Brasil where TI failed to get information in time to report on suspected corruption.

4. Those who may donate funds should do so through channels that apply anti-corruption best practices for health or any other sector for that matter.

5. Special courts to rapidly deal with COVID-19 cases of corruption and fraud should be established and adequately staffed with compete personnel.

6. Anti-corruption policies traditionally in place should be strengthened with the in-built of anti-corruption 
policies into the sector-based intervention design.

\section{References}

Bishop, T and Hydoski, F (2009), Corporate Resiliency Managing the growing Risk of Fraud and Corruption, John Wiley \& Sons, Inc., Hoboken, New Jersey, P21.

Ernst \& Young (2010), Fraud and Corruption in mining and metals: Focus on Business Ethics.

Evie, A (2020) COVID-19 Time Line 8 April 2020, UK Perspective

Leites, V.G (2020) Director of Uruguay Transpoarrente, Local Media.

Luminutan, I (2011), Fraud, Corruption in the Private Sector and Internal Control Quality.

Magaisa, (2020), Big Saturday Read, cited 01/08.2020.

Mahlaka, R (2020), Treasury Attempts to stop the feasting by Covid-preneurs, Business Maverick, 6 August 2020.

Paul, Fontenot, Oceania Fraud Investigation and Dispute Services 2019).

Pitse, R (2020), Sunday Standard, 8 June 2020

Planting, (2020), Business Maverick, March 2020.

PWC, 2010, Public Procurement: costs we pay for corruption (Official Journal).

Ronald J, Burke and Cooper C. L (2009), Research Companion to Corruption in Organisation, Edward Elgar Publishing Limited, the Lypiatts, Cheltenham, UK.

Steingruber, S et al. (2020), Corruption in the time of COVID-19: A double threat for low income countries, CHR Michelson Institute.

The Impact of COVID-19 on Good Governance and Anti-Corruption efforts in Latin America, 12 May 2020. 